JELTIS: Journal of English Language Teaching, Linguistics and Literature Studies

Volume 1. Number 1. August 2021

Available at http://journal.iain-manado.ac.id/index.php/jeltis/index

\title{
The Implementation of Student Team Achievement Division (STAD) To Motivate Students' Speaking Activity
}

\author{
Dewi Paputungan \\ Institut Agama Islam Negeri Manado \\ Dewi28paputungan@gmail.com \\ Nur Halimah \\ Institut Agama Islam Negeri Manado \\ nurhalimah@iain-manado.ac.id \\ Lies Kryati \\ Institut Agama Islam Negeri Manado \\ Lies.kryati@iain-manado.ac.id \\ Indah Wardaty Saud \\ Institut Agama Islam Negeri Manado \\ indah.saud@iain-manado.ac.id
}

\begin{abstract}
The Implementation of Students Team Achievement Division (STAD) to Motivate Students' Speaking Activity was a study which aimed to find out whether the implementation of Student Team Achievement Division (STAD) able to motivate students' speaking activity or not. The researcher used classroom action research design in this study. The subject was the class VIII B of eighth grade students of SMP Negeri 1 Sangkub consisting on 25 students which comprised 12 females and 13 boys. In this present research, the researcher used some instruments to collect the data, such as; Lesson Plan (RPP), Tests, observation, Interview, and documentation. In applying the test, the researcher asked the subject under the research to practice a simple dialogue about expression of giving instruction and expression of asking permission.

In this research, there were three cycles, namely; Pre-Cycle, Cycle I, and Cycle II. Furthermore, Cycle I and II consisted on two sessions. In Pre-Cycle, the completeness percentage was low (36\%) so that the present classroom action study was conducted to solve the problems of the students. The result of Cycle I showed that STAD motivated students' speaking activity. It could be seen from the increase of the completeness percentage of Cycle I (64\%). The researcher continued the research by conducting the Cycle II to revise the problem in Cycle I and the completeness percentage of Cycle II was (88\%). Based on the result above, the STAD technique has a positive influence to students of class VIII B at eighth grade students of SMP Negeri 1 Sangkub speaking activity, and this STAD Technique could be used to be one of the alternative teaching techniques.
\end{abstract}

Key Words: STAD, Motivate, Speaking Activity. 
JELTIS: Journal of English Language Teaching, Linguistics and Literature Studies Volume 1. Number 1. August 2021

Available at http://journal.iain-manado.ac.id/index.php/jeltis/index

Introduction

Speaking skill is very important in EFL courses. This is proved by the huge number of conversations and other speaking course books in the market. According to Scrivener, Fluency and confidence are the important goals of speaking skills, (Kristina, 2013). Generally, many learners want to try to speak something, but they do not know how to speak it so that the fluency and the confidence of the learners were lacking. The problem above causes a decrease in student's confidence in expressing their opinions or in this case communicating in English.

The one thing that they need is a motivation to motivate them to speak more or to awaken their confidence in speaking English. In developing the students' speaking activity, the teacher can use a teaching and learning technique to motivate them to develop their speaking activity. Suyanto (2009) in his book said that Social interaction which in this case is the communication between teacher to students and students to students can help the students in learning a new language. One of the ways to develop social interaction is learning in groups. The outcome of Learning in group that is to develop students' interaction is also in line with the goal of curriculum 2013. This curriculum implements the scientific approach (observing, questioning, experimenting, associating, and networking) in the learning process by using discovery learning. Discovery learning is a learning process that occurs when students did not get with information directly but students are obligated to organize their understanding of the information independently (Cahyo, 2013). This means in applying the discovery learning that the teacher acts as a guide by providing opportunities for students to learn actively and a facilitator for helping the students in learning activities in line with its objectives. The researcher concluded that discovery learning aims to change the learning process from teacher-oriented into student-oriented. Therefore, discovery learning needs to be applied in improving speaking skill.

In relation to the discovery learning and improve students' interest and confidence in speaking, the cooperative learning could be one of the ways to cover it. Cooperative learning is the learning process which involves the collaboration between two or more students or grouping. There are many teaching techniques in cooperative learning, and one of them is Student Team Achievement Division, (Slavin, 2015)

STAD is a cooperative learning methods which in the learning process the students will be separated in teams that consist of four or more students for each 
JELTIS: Journal of English Language Teaching, Linguistics and Literature Studies Volume 1. Number 1. August 2021

Available at http://journal.iain-manado.ac.id/index.php/jeltis/index

group and at the end of the learning process the students will be given individual quizzes; The researcher is interested in conducting a study about STAD technique to motivate students to learn English especially in speaking activity.Student Team Achievement Division (STAD) is one of types in cooperative learning that developed by Robert E. Slavin at John Hopkin University. Slavin state that STAD is the simplest cooperative learning which suitable for the teacher who are just begin to use cooperative learning.

Yeung (2015) elucidates that the fulfillment of instructional pedagogy is the basis to establish STAD. Mochtar and Jamaludin (2018) STAD is one of the cooperative learning methods that consist of small groups in which each member of the group work together to achieve the common goal. Mahmood, et al (2010) and Slavin (2011) respectively argued STAD is the easiest cooperative method that the teacher can apply and use to teach various subjects from any level. It is best used to teach mathematical application, language learning, geography, and natural science concept.

According to the explanations, STAD is a cooperative learning that implemented the team work who divided by a cross-section of the class in terms of academic performance, sex, race and so on. Thus, every group will be heterogeneous and has a smart student in each group so this smart student can help and motivate the other student in their group

There were several studies showed the advantages of employing STAD in teaching English skills. The first research is written by Khasanah (2014) under the title "The Influence Of Student Team Achievement Division (STAD) In Teaching Reading Comprehension At Tenth Grade Of SMAN 4 Kediri Academic Year 2014 / 2015" which focused on the implementation of STAD to find out the significant influence of students' reading comprehension and used the experimental design to obtained the data. Secondly, Kristina (2013) under the title "Improving Speaking Skill Through Student Teams Achievement Division (STAD) Of The Eleventh Grade Students Of SMKN 1 Tampaksiring In Academic Year 2013/2014". This research focused to improve students' at Hotel Management Academic (AP) of SMKN 1 Tampaskiring speaking skills through STAD. Thirdly, Setiabudi (2013) under the title "The Use of Student Team Achievement Division (STAD) Technique to Improve Student's Participation and reading comprehension". The researcher used the STAD technique to improve students' participation and reading comprehension. Fourthly, Nirmawati (2015) untitled Improving Students' Speaking Skills Through Speaking 
JELTIS: Journal of English Language Teaching, Linguistics and Literature Studies Volume 1. Number 1. August 2021

Available at http://journal.iain-manado.ac.id/index.php/jeltis/index

Board Games of Grade VIII of SMP N 13 Yogyakarta in The Academic Year of 2013/2014 which use the speaking board games to improve students' speaking skills. The lastly is Immaduddin (2011) entitled The Effectiveness of Using Student Team Achievement Division (STAD) technique in teaching Direct and Indirect Speech of Statement which used the quasi experimental research and focused on the use of STAD technique to improve students' understanding of direct and indirect speech of statement.

Based on those three previous studies, it could be seen that this study had the same aimed with those five previous studies that was to improve students' English skills. However, there was also a difference between this study with another studies. This difference can be seen from the main focus of this study which is to motivate the students speaking skills. So that the researcher expected that with the motivation received by students from the stimulus that given by the teacher through the STAD technique could increase students' interest in learning English, improve their participation in learning process and improve their speaking activity.

Based on the researchers' observation on $27^{\text {th }}$ November 2018 at SMP Negeri 1 Sangkub, the English teacher at eighth grade did not implementing the discovery learning. The learning process was still in lecturing class. In this classroom activity, the teacher spoke more than the students. This led to the non-performance of curriculum 2013, which emphasizes the ability of language as a communication tool, carrying knowledge and logical thinking, systematic, and creatively, (Ministry of education and Culture, 2013). Besides, Harmer states that to be a good teacher, the teacher should make their lesson interesting so the students are motivated to following the lesson (Harmer, 2001).

In accordance with the background of the research above, then the formulation of the problem in this study are:

1. Is the STAD technique able to motivate students' speaking activity?

2. To what extent does the implementation of STAD motivate students in speaking?

\section{Methodology}

This study used the Classroom Action Research design. Sudaryono states that classroom action research is a qualitative research conducted by the teacher to solve the teaching-learning problem with the aim to improve the learning quality, (Sudaryono, 2014) 
JELTIS: Journal of English Language Teaching, Linguistics and Literature Studies Volume 1. Number 1. August 2021

Available at http://journal.iain-manado.ac.id/index.php/jeltis/index

This study employed Lewin model those are planning, acting, observing, and reflecting. The relation of these four concepts was called a cycle. In planning stage, the researcher prepared the lesson plan, learning media, and instrument. Next, the researcher applied STAD technique to motivate student's speaking activity. The students who became participants were students in class VIII B at SMP Negeri 1 Sangkub. The researcher then conducted an observation stage at the same time during the leaning process. The researcher observed all the activity that happened during the learning process. The activity that the researcher observed was the activity that the students done during the learning process such as group discussion, the students' activeness during the learning process (both asking or answering question) and their success in doing the exercises. At the last stage, as a reflection, the researcher carry out reviewing and summarizing the result of observation, analyzing the action and notes taken by the researcher during the research process.

The instruments used by the researcher are 1) observation sheet; to gain the data of the phenomenon that happened in the research process in particular regarding to the employment of STAD, 2) Test; Pre-test has been given at the beginning of the study to determine student's responses about the learning process before get the treatment. The kind of test that the researcher used was the placement test. The purpose of this test was to measure student's understanding about asking opinion material and help the researcher in forming the students into teams. While post test had given at the end of the study to determine the students' responses about the learning process after receiving the treatment. This test helped the researcher in measuring the students' improvement.

The two other instruments are a guided interview protocol and a recorder to document all process. In this research, the researcher was done a guided interview to the students and the English teacher. In documentation, the researcher used the data of the school (including the teacher and the student's name), interviews' transcript, and picture as an evidence of the research.

This study used mix method, both qualitative and quantitative since it aims to describe the employment of STAD technique in improving students' motivation in speaking. In presenting qualitative data, the researcher used Miles and Huberman's steps (Data reduction, Data display, and data verifying). While for quantitative data, the researcher calculated the result of the students' learning outcomes which the researcher gained from the test result. The test that the researcher did in this 
JELTIS: Journal of English Language Teaching, Linguistics and Literature Studies Volume 1. Number 1. August 2021

Available at http://journal.iain-manado.ac.id/index.php/jeltis/index

research was pre-test and post-test. The percentage score would show the improvement was made by the students. Based on the curriculum of SMP Negeri 1 Sangkub and suggestion from the English teacher at eight grade, the minimum competence criteria (KKM) of the English subject was 75. Therefore, this classroom action research would be regarded to be successful if the $75 \%$ of subjects reaches the minimum score of 75 in teaching through STAD. It means that if the student has reached the criteria of success which was $75 \%$ of the student have passed the test then the action in this cycle would be finally stopped. In this research, two cycles were administered.

\section{Findings}

In cycle I, observation implemented in two meetings, On the first meeting, the researcher found that all the students in the class VIII B interested to learn by using STAD technique; they were curious and enjoyed the lesson. However, the researcher also found some problem in the learning process such as not all the students focused during the learning process, most of the students afraid to speak up during the learning activity; they are afraid to asking and answering questions even in Indonesian, and not all the students active in the group discussion. On the second meeting, the researcher obtained an improvement in students' activity during the lesson. All the students were active and paid their attention during the lesson, the students also prepared their learning stuff well and being active in asking and answering question by mixing Indonesian and English. But still, the researcher found some problem where the students afraid to practice to talk in front of the class.

In the cycle II, the observation process happened in two meetings. At the first meeting, the result of the observation showed that the students have increased their speaking activity. The students were active in asking and answering question, and also on the group cooperation. In line with the improvement of the student speaking activity, the students also improved their confidence to speak in English. Furthermore, in the second meeting, the student showed up a significant improvement on their speaking skill especially in the aspect of the vocabulary, pronunciation, and fluency.

Further, the interview was conducted before and after the treatment. The researcher had interviewed 10 students and the English teacher. Based on the 
JELTIS: Journal of English Language Teaching, Linguistics and Literature Studies Volume 1. Number 1. August 2021

Available at http://journal.iain-manado.ac.id/index.php/jeltis/index

results of researchers' interviews with several participants before the pre-test, the following interview results were obtained.

1) The main problem in the classroom was the communication between the teacher and the student that not going well. This was showed by the teacher statement that "The student is passive during the learning process, they spoke less during the learning process and if they speak then they used Indonesian but in English they do not want to" this statement is in accordance with the students which most of them said that "saya takut salah" (I am afraid of being wrong), "Saya tidak mengerti, takut, dan malu" (I do not understand, afraid, and shy), and "Saya takut salah dan ditertawaka teman-teman" (I am afraid to speak wrong and being laughed by my classmates).

2) The learning process still used the teacher centered learning, this is proved by the students answer which said " kami tidak pernah belajar dalam kelompok" (we are never learning in groups), "kami pernah belajar dalam kelompok ketika kelas 7" (we do ever learned in group on the seventh grade). in addition, Mrs. Suriani Banteng, S.Pd said that "Grouping is good but I thought the class will be noisy. That is why I use the teacher centered learning in teaching process."

Based on the phenomenon above, the researcher tried to solve the problem by using Student team Achievement Division (STAD) Technique in teaching English.

The second interview was done after the treatment, the researcher had interviewed the English teacher after the implementation of the STAD technique. The interview result as follow:

1)The students were active in the learning process. The teacher said that "It is very good. The students were active in the learning process. Formerly they not really active in the learning process and seems like they are afraid to speak. But now, they are confidence to speak during the learning process."

2) The students were improved their speaking skills, this was supported by the teachers' statement which said "Now they can speak in confidence" and "Based on the test, they got a great score. This statement was powered by the students' scores improvement in every test after the cycle. 
JELTIS: Journal of English Language Teaching, Linguistics and Literature Studies

Volume 1. Number 1. August 2021

Available at http://journal.iain-manado.ac.id/index.php/jeltis/index

Pre-cycle

In the classroom action research, the first step that the researcher doing was pre-test or initial reflection about the research subject to obtain their preexisting ability in speaking before the treatment. In this pre-cycle, the researcher has done several steps to obtain the data, they are:

1)The researcher and the English teacher were both in the classroom;

2) The teacher presented the material while the researcher became the observer that observed the learning process; based on the researchers' observation during the learning process, the teacher used the teacher center learning which caused the lack of students' speaking intensity and learning motivation.

3) At the end of learning process, the researcher and the teacher evaluated the students to determine the initial result of the students.

The student pre-cycle evaluation results are as follows:

Table 4.1

The pre-cycle evaluation results

\begin{tabular}{l|l|c|c|c}
\hline \multirow{2}{*}{ No } & & \multirow{2}{*}{ Name } & Pre-Cycle & \multicolumn{2}{|c}{ Explanation } \\
\hline & & Score & Passed & Failed \\
\hline 1 & AP & 37.5 & & $\checkmark$ \\
\hline 2 & IAOM & 43.75 & & $\checkmark$ \\
\hline 3 & DM & 75 & $\checkmark$ & \\
\hline 4 & BS & 25 & & $\checkmark$ \\
\hline 5 & CAD & 81.25 & $\checkmark$ & \\
\hline 6 & VP & 43.75 & & $\checkmark$ \\
\hline 7 & FS & 75 & $\checkmark$ & \\
\hline 8 & FP & 75 & $\checkmark$ & \\
\hline 9 & FIW & 81.25 & $\checkmark$ & \\
\hline 10 & IL & 25 & & $\checkmark$ \\
\hline 11 & KO & 25 & & $\checkmark$ \\
\hline 12 & LM & 75 & $\checkmark$ & \\
\hline 13 & MM & 25 & & $\checkmark$ \\
\hline 14 & MAG & 50 & & $\checkmark$ \\
\hline 15 & MDP & 81.25 & $\checkmark$ & \\
\hline 16 & MFS & 31.25 & & $\checkmark$ \\
\hline 17 & PFK & 75 & $\checkmark$ & \\
\hline 18 & RS & 25 & & $\checkmark$ \\
\hline 19 & RK & 37.5 & & $\checkmark$ \\
\hline 20 & RM & 31.25 & & $\checkmark$ \\
\hline 21 & SK & 31.25 & & $\checkmark$ \\
\hline 22 & SP & 81.25 & $\checkmark$ & \\
\hline 23 & SM & 37.5 & & \\
\hline 24 & TAH & 43.75 & & $\checkmark$ \\
\hline 25 & WP & & & \\
\hline & & & \\
\hline
\end{tabular}


JELTIS: Journal of English Language Teaching, Linguistics and Literature Studies Volume 1. Number 1. August 2021

Available at http://journal.iain-manado.ac.id/index.php/jeltis/index

\begin{tabular}{r|r|c|c|c}
\hline \multirow{2}{*}{ No } & \multirow{2}{*}{$\begin{array}{c}\text { Pre-Cycle } \\
\text { Name }\end{array}$} & Score & Passed & Failed \\
\cline { 3 - 5 } & Total & 1237.5 & - & - \\
\hline & The Highest Score & 81.25 & - & - \\
\hline The Lowest Score & 25 & - & - \\
\hline Average & 49.5 & - & - \\
\hline
\end{tabular}

The students' completeness percentage value was obtained by dividing Sigma $X\left(\sum x\right)$, which is the total students that got score 75 or more at the test that is 9 students with Sigma $N\left(\sum N\right)$, the total students which is 25 then multiplied by $100 \%$ and the result is $36 \%$.

The main figure of the pre-cycle was said low because the completeness percentage did not achieve $75 \%$ yet. It could be seen from the average value that was 42.45 and the completeness percentage that the student got which was $32 \%$.

\section{Cycle I}

Table 4.2

Cycle I Evaluation Result

\begin{tabular}{l|l|c|c|c}
\hline \multirow{2}{*}{ No } & & \multirow{2}{*}{ Name } & Cycle I & \multicolumn{2}{c}{ Explanation } \\
\cline { 4 - 5 } & & Score & Passed & Failed \\
\hline 1 & AP & 56.25 & & $\mathbf{V}$ \\
\hline 2 & IAOM & 81.25 & $\mathbf{V}$ & \\
\hline 3 & DM & 87.5 & $\mathbf{V}$ & \\
\hline 4 & BS & 43.75 & & $\mathbf{V}$ \\
\hline 5 & CAD & 87.5 & $\mathbf{V}$ & \\
\hline 6 & VP & 75 & $\mathbf{V}$ & \\
\hline 7 & FS & 75 & $\mathbf{V}$ & \\
\hline 8 & FP & 93.75 & $\mathbf{V}$ & \\
\hline 9 & FIW & 81.25 & $\mathbf{V}$ & \\
\hline 10 & IL & 50 & & $\mathbf{V}$ \\
\hline 11 & KO & 75 & $\mathbf{V}$ & \\
\hline 12 & LM & 81.25 & $\mathbf{V}$ & \\
\hline 13 & MM & 56.25 & & $\mathbf{V}$ \\
\hline 14 & MAG & 75 & $\mathbf{V}$ & \\
\hline 15 & MDP & 81.25 & $\mathbf{V}$ & \\
\hline 16 & MFS & 75 & $\mathbf{V}$ & \\
\hline 17 & PFK & 75 & $\mathbf{V}$ & \\
\hline 18 & RS & 50 & & $\mathbf{V}$ \\
\hline 19 & RK & 75 & $\mathbf{V}$ & $\mathbf{V}$ \\
\hline 20 & RM & 58.75 & & $\mathbf{V}$ \\
\hline 21 & SK & 53.75 & & $\mathbf{V}$ \\
\hline 22 & SP & 81.25 & $\mathbf{V}$ & \\
\hline 23 & SM & 93.75 & $\mathbf{V}$ & \\
\hline 24 & TAH & 43.75 & & \\
\hline 25 & WP & $\mathbf{1 7 5 6 . 2 5}$ & $\mathbf{}$ & \\
\hline & & & & \\
\hline & & & & \\
\hline
\end{tabular}


JELTIS: Journal of English Language Teaching, Linguistics and Literature Studies Volume 1. Number 1. August 2021

Available at http://journal.iain-manado.ac.id/index.php/jeltis/index

\begin{tabular}{r|r|c|c|c}
\hline \multirow{2}{*}{ No } & \multirow{2}{*}{ Name } & \multirow{2}{*}{$\begin{array}{c}\text { Cycle I } \\
\text { Score }\end{array}$} & \multicolumn{2}{c}{ Explanation } \\
\cline { 3 - 5 } & & 93.75 & - & Failed \\
\hline & The Highest Score & 93.75 & - & - \\
\hline The Lowest Score & 43.75 & - & - \\
\hline Average & 70.25 & - & - \\
\hline
\end{tabular}

The average value was the total score of the students $\left(\sum x\right)$ which is 1750 were divided by the total students $\left(\sum N\right)$ that is 25 then the result is 70 . The students' completeness percentage value was obtained by dividing Sigma $X\left(\sum x\right)$, which is the total students that got score 75 or more at the test that is 16 students with Sigma $\mathrm{N}$ $\left(\sum N\right)$, the total students which is 25 then multiplied by $100 \%$ and the result is $64 \%$.

\section{Cycle II}

The students' evaluation results as follows:

Table 4.3

Cycle II Evaluation Result

\begin{tabular}{|c|c|c|c|c|}
\hline \multirow{2}{*}{ No } & \multirow{2}{*}{ Name } & \multirow{2}{*}{$\begin{array}{l}\text { Cycle II } \\
\text { Score }\end{array}$} & \multicolumn{2}{|c|}{ Explanation } \\
\hline & & & Passed & Failed \\
\hline 1 & AP & 81.25 & $\checkmark$ & \\
\hline 2 & IAOM & 93.75 & V & \\
\hline 3 & $\mathrm{DM}$ & 81.25 & $\sqrt{ }$ & \\
\hline 4 & BS & 62.5 & & V \\
\hline 5 & CAD & 87.5 & V & \\
\hline 6 & $\mathrm{VP}$ & 81.25 & 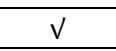 & \\
\hline 7 & FS & 81.25 & $\checkmark$ & \\
\hline 8 & $\mathrm{FP}$ & 93.75 & $\checkmark$ & \\
\hline 9 & FIW & 87.5 & 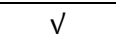 & \\
\hline 10 & IL & 75 & $\mathrm{~V}$ & \\
\hline 11 & $\mathrm{KO}$ & 75 & $\checkmark$ & \\
\hline 12 & LM & 87.5 & 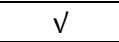 & \\
\hline 13 & MM & 75 & 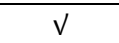 & \\
\hline 14 & MAG & 81.25 & 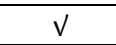 & \\
\hline 15 & MDP & 87.5 & $\checkmark$ & \\
\hline 16 & MFS & 81.25 & $\checkmark$ & \\
\hline 17 & PFK & 87.5 & $\checkmark$ & \\
\hline 18 & RS & 75 & $\checkmark$ & \\
\hline 19 & RK & 81.25 & $\checkmark$ & \\
\hline 20 & RM & 68.75 & & $\sqrt{ }$ \\
\hline 21 & SK & 81.75 & $\mathrm{~V}$ & \\
\hline 22 & SP & 93.75 & V & \\
\hline 23 & SM & 75 & $\checkmark$ & \\
\hline 24 & TAH & 62.5 & & $\sqrt{ }$ \\
\hline 25 & WP & 87.5 & $\checkmark$ & \\
\hline & Total & 2025 & - & - \\
\hline
\end{tabular}


JELTIS: Journal of English Language Teaching, Linguistics and Literature Studies Volume 1. Number 1. August 2021

Available at http://journal.iain-manado.ac.id/index.php/jeltis/index

\begin{tabular}{r|c|c|c}
\hline The Highest Score & 93.75 & - & - \\
\hline The Lowest Score & 62.5 & - & - \\
\hline Average & 81 & - & - \\
\hline The Completeness Percentage & $88 \%$ & - & - \\
\hline
\end{tabular}

The average value was the total score of the students $\left(\sum x\right)$ which is 2025 were divided by the total students $\left(\sum N\right)$ that is 25 then the result is 81 . The students' completeness percentage value was obtained by dividing Sigma $X\left(\sum x\right)$, which is the total students who have met the KKM at the test that is 22 students with Sigma $N\left(\sum N\right)$, the total students which is 25 then multiplied by $100 \%$ and the result is $88 \%$.

\section{Discussion}

\section{The Implementation of STAD (Student Team Achievement Division) technique}

In this research, the researcher was implemented the STAD technique to motivate students' in class VIIIB at SMP Negeri 1 Sangkub speaking activity. STAD is the simplest type of cooperative learning which developed by Robert E. Slavin. In this learning technique, the students would be divided into heterogeneous groups which could motivate students to improve their learning outcomes. The teaching and learning process by using STAD technique in teaching English become better because the students could easily understand the material by discussing it with their classmates. Through team work there would be communication and interaction between students to share their ideas, to express their own opinion, and to accustoming students to speak confidently.

Based on the research conducted, the findings showed that many students who understand the material could provide assistance in learning to students who do not understand the material. This can foster learning motivation for students, and have a positive impact on their learning outcomes. However, in the implementation of STAD technique in the cycle I there were still some weaknesses:

a. The students afraid to speak up during the learning process.

b. The students afraid to asking and answering question.

c. The students' cooperation in group discussion was less.

d. Not all the students focused during the learning process.

e. Some students did not achieve the minimum completeness criteria (KKM). 
JELTIS: Journal of English Language Teaching, Linguistics and Literature Studies

Volume 1. Number 1. August 2021

Available at http://journal.iain-manado.ac.id/index.php/jeltis/index

Based on the weakness on the cycle I, the researcher made some improvements in the learning process in the cycle II. The improvements in the cycle II as follow:

a. The researcher as the teacher gave motivation and supported the students asking and answering questions, and also to provide their arguments during the lesson.

b. The students' cooperation in groups was more optimized.

The result of the implementation of the STAD technique in the cycle II showed an increase in learning outcomes of all students. When compered with the student learning outcomes in the cycle I, the student learning outcomes in the cycle II have increased.

\section{Students' learning outcomes}

Learning outcomes are the abilities obtained by the students from teaching and learning process in accordance with the learning objectives. Thus, the learning outcomes could also reflect the students' ability to understand the learning material. In this research, the test given to the students were make a simple dialogue about the material that have been taught before, and practice that dialogue in front of the class. The material on the cycle I was expression of giving instruction and expression of asking permission for cycle II.

Based on the findings, the implementation of STAD technique is able to improve the students' learning outcomes. This is proved by the increasing of the students' completeness percentage from the pre-cycle until the cycle I and cycle II.

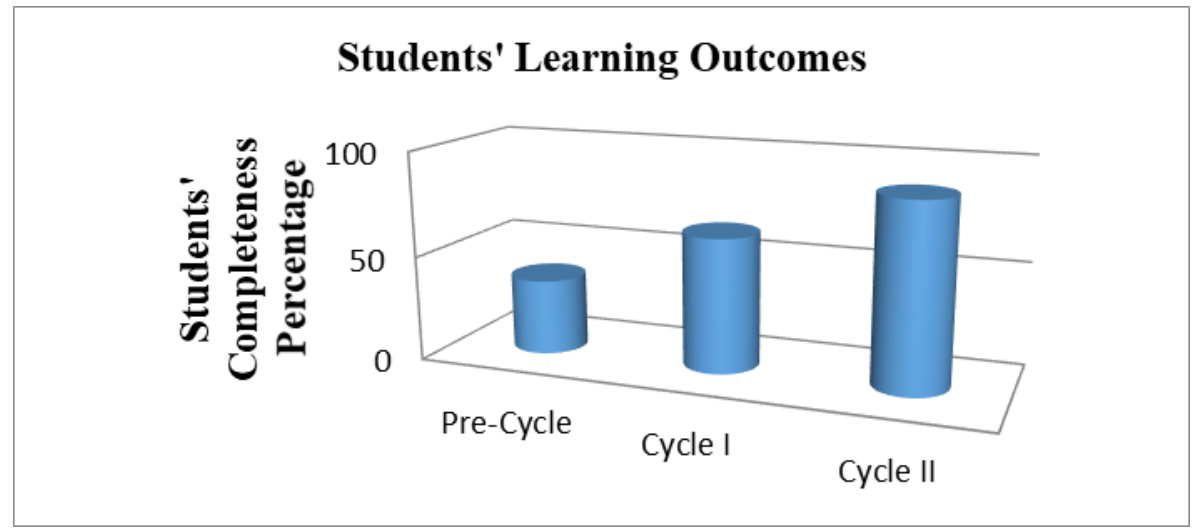


JELTIS: Journal of English Language Teaching, Linguistics and Literature Studies Volume 1. Number 1. August 2021

Available at http://journal.iain-manado.ac.id/index.php/jeltis/index

According to the figure, it could be seen that there was an increasing of students' learning outcomes from the pre-cycle, cycle I, and the cycle II. The results obtained in pre-cycle are point out $36 \%$ or 9 students from the total 25 students passed the score of minimum completeness criteria (KKM) which is 75 . While in the cycle I, the student learning outcomes showed an increasing score. There were 16 of 25 students passed the test and 9 students failed at the test so that the completeness percentage was $64 \%$. Moreover, in the cycle II the result showed an increasing of all the students' learning outcomes. The total students that reached the KKM was 23 students and the 2 others did not reach the KKM value so the completeness percentage was $88 \%$.

Based on the results obtained, the researcher concluded that the student learning outcomes has increased after the implementation of the STAD technique in the teaching and learning process. Therefore, in the teaching and learning activity, appropriate teaching techniques are needed so that better learning condition could be created to improve the students' learning outcomes. This is in line with the Slavin statement (2015) that the application of the technique could provide opportunities for students to work together in doing their group assignment. Each student could help each other in understanding the material or assignments given by the teacher and always active in the learning process. By using this STAD technique, the students could think more creatively, encourage students' confidence and skills, and take responsibility in learning activity, so that the students' learning outcomes would be improved. Thus, the application of STAD technique in English subject could be an alternative to motivate students' speaking activity and improve students' learning outcomes.

\section{Conclusion}

The researcher concluded two conclusions to answer the research problem. The conclusion as follows: (1)The implementation of STAD technique in class VIIIB of SMP Negeri 1 Sangkub is able to improve the quality of teaching and learning process especially in motivating students' speaking activity. This is proved by the findings which showed the improvement of the students' speaking activity during the lesson such as the students were more active in asking and answering questions, enthusiastic in the discussion activity, and also improved their learning outcomes, (2)The implementation of STAD technique in teaching English subject at 


\section{JELTIS: Journal of English Language Teaching, Linguistics and Literature Studies Volume 1. Number 1. August 2021}

\section{Available at http://journal.iain-manado.ac.id/index.php/jeltis/index}

class VIIIB of SMP Negeri 1 Sangkub has done in two cycles. The application of STAD technique in teaching process in addition to increasing students' speaking activity also increased the students' learning outcomes. In the Pre-test, the result showed that the completeness percentage was $36 \%$ or as many as 9 students that passed the test; while the 16 other students was filed. This result is stated very low from the criteria of the completeness percentage which is $75 \%$. In the Cycle I, the completeness percentage of the student who passed the test increase into $64 \%$ of as many as 16 students that passed the test. Meanwhile, this result is not reaching the criteria of completeness percentage. In the Cycle II, the result of completeness percentage became $88 \%$ or 23 students. The results obtained have passed the percentage of students' completeness that must be achieved. Furthermore, it is suggested that future researchers examine the effectiveness of STAD technique when it is compared to another technique in experimental research.

\section{References}

Kristina, Kadek. 2013. Improving Speaking Skill Through Student Teams Achievement Division (STAD) Of The Eleventh Grade Students Of SMKN 1 Tampaksiring In Academic Year 2013/2014. Thesis, Faculty Of Teacher Training And Education Mahasaraswati Denpasar University Denpasar.

Suyanto, Kasihani. 2009. English for Young Learners, Jakarta: Bumi Aksara.

Cahyo N, Agus. 2013. Panduan Aplikasi Teori-Teori Belajar Mengajar, Wonosari: Diva Press

Slavin, Robert, 2015, Cooperative learning: theory, research and practice, translate. Narulita Yusron, Bandung: Nusa Media.

Yeung, Chim Ho. 2015. Literature Review of the Cooperative Learning StrategyStudent Team Achievement Division (STAD.) International Journal of Education, Vol. 7, No. 1.

Jamaludin, Mazlina and Mochtar, Muhammad Fauzi. 2018. Student Team Achievement Division International Journal of Academic Research in Business and Social Sience, Vol. 8, No. 2. 
JELTIS: Journal of English Language Teaching, Linguistics and Literature Studies Volume 1. Number 1. August 2021

Available at http://journal.iain-manado.ac.id/index.php/jeltis/index

Khasanah, Miftahul. 2014. The Influence Of Student Team Achievement Division (Stad) In Teaching Reading Comprehension At Tenth Grade Of SMAN 4 Kediri Academic Year 2014 / 2015, Thesis, Faculty Of Teacher Training And Education University Of Nusantara Pgri Kediri.

Kristina, Kadek. 2013. Improving Speaking Skill Through Student Teams Achievement Division (STAD) Of The Eleventh Grade Students Of SMKN 1 Tampaksiring In Academic Year 2013/2014. Thesis, Faculty Of Teacher Training And Education Mahasaraswati Denpasar University Denpasar.

Setiabudi, Aris. 2013. The Use of Student Team Achievement Division (STAD) Technique to Improve Student's Participation and reading comprehension (A Classroom Action Research at the Eleventh Grade Studens of SMA Negeri 1 Mejobo Kudus in Academic Year 2012/2013. Thesis, Faculty of Teacher Training and Education University of Muria Kudus

Nirmawati, Lia Amalia. 2015. Improving Students' Speaking Sklikks Through Speaking Board Games of Grade VIII of SMPN 13 Yogyakarta in The Academic Year of 2013/2014. Thesis, Faculty of Languages and Arts Yogyakarta State University.

Imaduddin, Fahmi. 2011. The Effectivenes of Using Student Team Achievement Division (STAD) Technique in Teaching Direct and Indirect Speech of Statement (a Quasi Experimental Study at the Eleventh Garedof Jam'iyyah Islamiyyah Islamic Senior High School Ceger). Thesis, Faculty of Tarbiya and Teachers' Training, Syarif Hidayatullah State Islamic University Jakarta.

Harmer, Jeremy. 2001. How To Teach English. England: Longman 